\title{
Forms and Distribution of Carbon in Soils of Dambal Sub-Watershed of Mundargi Taluk, Gadag District, Karnataka, India
}

\author{
K. S. Harshith Gowda, B. R. Jagadeesh* and P. L. Patil
}

Department of Soil Science and Agricultural Chemistry, UAS, Dharwad, College of Agriculture, Hanumanamatti-581115, Ranebennur(T), Haveri(D), Karnataka, India

*Corresponding author

\section{A B S T R A C T}

\section{Ke y w o r d s \\ Carbon fractions, Soil profile, Sub- watershed, Soil series, \\ Exchangeable cations}

\section{Article Info}

Accepted:

10 July 2020

Available Online:

10 August 2020
A study on forms and distribution of carbon in the soils of Dambal sub-watershed of Mundargi taluk of Gadag district, Karnataka was undertaken during 2018-19. One representative soil profile for each soil series was selected to represent twenty two soil series identified under Sujala-III project. Depth wise soil samples were collected and analysed for forms of carbon. Soils were generally sandy clay loam to clay in texture, bulk density and particle density increased with depth and on contrary porosity was decreased with depth. The $\mathrm{pH}$ and EC values ranged from neutral to strongly alkaline and normal to strongly saline respectively. Organic carbon content followed decreasing trend with depth and irregular distribution was observed in free $\mathrm{CaCO}_{3}$. $\mathrm{CEC}$ of soil series was average with $\mathrm{Ca}^{2+}$ found as dominant exchangeable cation followed by $\mathrm{Mg}^{2+}, \mathrm{Na}^{+}$and $\mathrm{K}^{+}$. Majority of soils possessed medium to high per cent base saturation. Organic, water soluble and active carbon fractions were decreased with depth in all the soil series, whereas inorganic and total carbon did not follow a particular trend. Water soluble and active carbon showed significant positive correlation with organic carbon, whereas inorganic and total carbon showed significant and positive correlation with $\mathrm{CaCO}_{3}$. Organic, water soluble and active carbon were significantly and positively correlated with each other, whereas inorganic and total carbon was significantly and positively correlated with each other.

\section{Introduction}

Soil indeed alive and dynamic system consisting of minerals and microorganisms, the top-most layer of soil is comparatively richer in nutrients and supports maximum bio-resource. The profile character varies distinctly from place to place, particularly with respect to their depth, colour and composition. The mineral composition of the soil, organic matter within it and environment, all these are resolute by chemical, physical and biological properties of soil.

Soil organic carbon is necessary for improving soil quality, sustaining food production and sinking $\mathrm{CO}_{2}$ in the atmosphere, whereas its inorganic counterpart (free $\mathrm{CaCO}_{3}$ ) is the cause of organic carbon decomposition, restricting root proliferation, developing salinity (Eswaran and Van den 
berge, 1992) and immobilizing soil plasma. Moreover, average annual precipitation, period of canopy cover, tillage, available moisture content, silt and clays have noticeable effects on dynamics of soil carbon. Periodical evaluation of $\mathrm{OC}$ is important in semi-arid and arid regions. Attenuation of water resources, periodic drought, severe erosion and summer fallowing has a detrimental effect on SOC level.

As the interface between the atmosphere, lithosphere and biosphere, soil undergoes an intense vertical interchange of materials causing in sharp physical and chemical gradients from surface to bedrock. Stratification of soil is the most noticeable outcome of this interchange and its extensive reflection and synthesis form the basis of pedogenetic and taxonomical study. The type, thickness, and arrangement of horizons can gives information about soil forming factors such as climate, time, topography and vegetation type. Similarly, the vertical distribution of nutrients in soil should yield related insights into nutrient cycling processes (Smeck, 1973; Kirby, 1985).

Watershed is a natural geo-hydrologic entity that encompasses a specific area stretch of land surface, where water from rainfall or run off flows to a specific defined drain it may be a channel, naala and small stream or river. The term Sub-watershed indicates hierarchical division considered appropriate unit for both survey, assessment of soil and land resources as well as for planning and implementation of watershed management practices.

\section{Materials and Methods}

Dambal sub-watershed (Mundargi taluk, Gadag district) is selected as study area is located in Northern dry zone of Karnataka between $15^{\circ} 15^{\prime} 07^{\prime \prime}$ to $15^{\circ} 19^{\prime} 30^{\prime \prime}$ North latitudes and $75^{\circ} 41^{\prime} 15^{\prime \prime}$ to $75^{\circ} 48^{\prime} 26^{\prime \prime}$ East longitudes, covering an area of about 4749.89 ha (Fig. 1) and subjected to the detail of LRI using IRS P6 LISS IV data at 1:50,000 scale in Sujala-III project. Soil resources are mapped at soil phase level and identified 22 soil series (Anon., 2017). The major parent material in the sub-watershed is weathered schist and granite gneiss, climate of the area is semi-arid or hot tropical and monsoonic type. The entire sub-watershed has diversified crop, climate and soils comprises of both red gravelly clay and deep clay soils differing in their physical and chemical characteristics. The soil depth was very shallow to very deep and gradient of land was nearly level to very gently sloping. The soil is moderately eroded and some portion of the soil comes under slight eroded class.

One representative soil profile was selected from each soil series and horizon-wise soil samples were analyzed for vertical distribution of forms of carbon. Processed soil samples $(<2 \mathrm{~mm})$ were analyzed for different physico-chemial properties using following standard procedures.

The soil samples were analyzed for particle size distribution (Piper, 2002), bulk and particle density by Black (1965). pH (1:2.5), EC (1:2.5) and OC by Walkley and Black's wet oxidation method (Sparks, 1996). Free $\mathrm{CaCO}_{3}$ (Piper, 2002), CEC and Exchangeable bases by (Jackson, 1973). The organic carbon content of finely ground $(0.2 \mathrm{~mm})$ soil samples was determined by using Walkley and Black's wet oxidation method (Sparks, 1996). The water soluble carbon was determined using the method as described by Mc Gill et al., (1986). In brief, $10 \mathrm{~g}$ of soil was shaken for 1 hour with $20 \mathrm{ml}$ of soil, followed by centrifugation $(6000 \mathrm{rpm})$, filtration and titration against standard ferrous sulphate. The active carbon was determined by the modified method of Blair et al., (1995) 
as outlined by Weil et al., (2003). In brief, active carbon was determined by shaking $5 \mathrm{~g}$ air dried soil with $20 \mathrm{ml}$ of $0.02 \mathrm{M} \mathrm{KMnO}_{4}$ for 2 minutes (horizontal shaker-120 rpm), followed by centrifugation and measuring the light absorbance at $550 \mathrm{~nm}$ by colorimeter. The inorganic carbon (free calcium carbonate) content of soil samples was determined by rapid acid titration method as described by Piper (2002) and expressed in $\mathrm{g} \mathrm{kg}^{-1}$. Total carbon was determined by using CHNS analyzer (Vario EL cube model) by Dhaliwal et al., (2011). The experimental results were subjected to statistical analysis adopting Fisher's method of analysis of variance as outlined by Gomez and Gomez (1984). Testing of significance was done by SPSS 16.0 version and values are given at 5 per cent and 1 per cent level of significance.

\section{Results and Discussion}

\section{Physical properties of soil}

The particle size analysis showed that the texture of the different soil profile of the different soil series was sandy clay loam to clay in nature. The sand, silt and clay content in soil profiles varied from 12 to 62,10 to 32 and 24 to 73 per cent, respectively. The highest values of sand silt and clay per cent observed in JLG, NGT and BLD series respectively. This is might be due to topography, in-situ weathering and translocation of clay (Thangasamy et al., 2005). It was further observed that the particle size analysis did not follow any pattern with soil depth. While, lowest values showed in KPR, MJR and JLG series respectively. The mean value of sand $(33.27 \%)$, silt (19.97\%) and clay (46.77\%) was recorded in different soil series. More amount of sand content (JLG series) was usually observed in upper horizons than sub-surface horizons, while clay content in majority of the soil series increasing with respect to depth. Highest value of clay observed in BLD series and lowest in JLG series. The amount of clay increased with increasing profile depth was attributed due to illuviation of the finer fraction to the lower horizons. These conformities were also lined with observations recorded by Chari (2015) and Prathibha (2016).

Bulk density and particle density of the different soil profile of the different soil series were ranged from 1.19-1.51 $\mathrm{Mg} \mathrm{m}^{-3}$ and 2.60$2.65 \mathrm{Mg} \mathrm{m}^{-3}$ respectively. The lowest and highest value of bulk and particle densities was observed in (MTL and DNI series) and (CKP and HHG series) respectively. The mean value of both the parameters was observed as $1.36 \mathrm{Mg} \mathrm{m}^{-3}$ and $2.62 \mathrm{Mg} \mathrm{m}^{-3}$, showed increasing trend with increase in depth in all soil series. Soils possessed higher values of bulk density observed in lower horizons of soil profile compared to surface horizons in all soil series. It might be due to high smectite clay leading to compaction and formation of slicken sides, leading to strong structural aggregate formation and more compaction of finer (clay) particles in lower layers caused by over-head weight of the surface layers. The low bulk density values of surface horizons could be accredited due to higher organic matter. The increased bulk density with depth was attributed to increased compaction due to the load of overlying horizons (Nagendra and Patil, 2015) and (Thangasamy et al., 2005). Porosity values varied from 42.37 (CKP series) to 54.58 (MTL series) in per cent and followed a decreasing trend along the depth in all the profiles. Porosity of the soil series varied with one profile to another, due to variation in bulk and particle density of the soil profile. This was mainly influenced due to organic matter and clay content of soil. Higher per cent porosity was observed in surface horizons as compared to sub surface horizons. As organic matter content increases the soil pore space 
increases. These outcomes were also matched with the result of Meenkshi Bai et al., (2018).

\section{Chemical properties of soil}

Soil reaction values ranged from 6.72 to 9.27 , which representing that the soils were neutral to strongly alkaline in nature with mean value of 8.11. Among twenty two profiles, BLD and VRV series showed minimum and maximum value of $\mathrm{pH}$ respectively. It didn't showed definite trend along with depth. The alkaline $\mathrm{pH}$ of soil was due to semi-arid climate characterized by high evapotranspiration and less precipitation leading to accumulation of higher amount of basic cations in the soil. Similar results and inferences were also drawn by Vinay (2007) in the soils of Bhanapur micro-watershed of Karnataka. EC (Salinity) of the soils varied from 0.08 to 1.84 $\mathrm{dS} \mathrm{m}{ }^{-1}$ indicating the soils were normal to strongly saline in nature; this might be due to excess salt contained in irrigation water. The least value of EC was observed in MJR series and highest in NGT series, $0.51 \mathrm{dS} \mathrm{m}^{-1}$ was an average value of EC. Soluble salt content in the soil profiles not followed a definite trend with the depth. Irregular variation in EC could presently due to movement of salt from surface to down level through the percolation of water and subsequent accumulation at places during evapotranspiration resulting in differential salt accumulation along the pedons. Similar observations were recorded by Anjali and Hebbara (2017). The OC content varied from 1.8 to $6.8 \mathrm{~g} \mathrm{~kg}^{-1}$ and decreased with depth in all soil series. On an average of OC content was observed in all the series was $4.16 \mathrm{~g} \mathrm{~kg}^{-1}$ and SGT had a minimum value of OC, while MTL recorded maximum value. The organic carbon content of different soil series was under low to medium category. It was further observed that the OC content was more at surface layers than lower layers of the soil profiles, as the depth increases organic carbon also decreases in Dambal study area. The lower value of OC might be due to semi-arid climate which leads to faster decomposition of organic matter and this fact observed in SGT series. Similar trend was reported by Patil and Patil (2018) for soils of Kanagihal sub-watershed.

Free calcium carbonate content in soil had a mean value of $136.66 \mathrm{~g} \mathrm{~kg}^{-1}$ and ranged from 36.2 (SGT series) to 472.5 (VKP series) $\mathrm{g} \mathrm{kg}^{-}$ 1 . Majority of the profiles comes under calcareous behaviour and increased with depth in HHG, BLD, MJR, VKP, NPT, AKT, DNI and MVD series, while KPR series was showed decreasing trend with respect to profile depth and remaining soil series, not followed any definite trend. This might be due to illuviation along with clay and predominance of free calcium carbonate in lower horizons as compared to the surface horizons attributed to the leaching of soluble salts, free calcium and semi-arid climate favors calcification process leading to accumulation of free $\mathrm{CaCO}_{3}$ in these soils. The CEC of soil series ranged from 12.29 to $49.78 \mathrm{cmol}\left(\mathrm{p}^{+}\right) \mathrm{kg}^{-1}$ and mean value was $29.20 \mathrm{cmol}\left(\mathrm{p}^{+}\right) \mathrm{kg}^{-1}$. The highest and lowest content was recorded in MVD and KLK series respectively and values were not in consistency with depth. The magnitude of CEC was an indicative of presence of mixed type of clay minerals in the pedons. Variation in clay content and type, OC and presence of free iron oxides were responsible for variation in CEC in different pedons at varying physiographic positions. This was in concordance with the observations made by Pramod and Patil (2015) and Sitanggang et al., (2006).

Exchangeable calcium and magnesium content in the soils ranged from 5.6 (KLK) to 37.5 (MVD) cmol $\left(\mathrm{p}^{+}\right) \mathrm{kg}^{-1}$ and 1.6 (AKT) to 11.7 (NGT) cmol $\left(\mathrm{p}^{+}\right) \mathrm{kg}^{-1}$, respectively. The exchangeable sodium ranged from 0.12 (KLK) to 2.07 (KPR) cmol $\left(\mathrm{p}^{+}\right) \mathrm{kg}^{-1}$, while 
exchangeable potassium varied from 0.18 (SGT \& MJR) to 0.90 (VRV) $\mathrm{cmol}\left(\mathrm{p}^{+}\right) \mathrm{kg}^{-1}$. On an average value of $\mathrm{Ca}^{2+}, \mathrm{Mg}^{2+}, \mathrm{Na}^{+}$and $\mathrm{K}^{+}$was $19.29,5.92,0.78$ and 0.32 in $\mathrm{cmol}$ $\left(\mathrm{p}^{+}\right) \mathrm{kg}^{-1}$ respectively. The predominance of exchangeable cations in majority of soil series was followed an order: $\mathrm{Ca}^{2+}>\mathrm{Mg}^{2+}>\mathrm{Na}^{+}>$ $\mathrm{K}^{+}$and not showed any particular trend with depth. This order of dominance was in accordance with Pinki et al., (2017), viewed that leaching causes preferential losses of $\mathrm{Na}^{+}$ and $\mathrm{K}^{+}$. Due to preferential leaching of monovalent, this leads to lower value of exchangeable monovalent compared to divalent. Similar results were reported by Anjali and Hebbara (2017). This was apparently due to the difference in the parent material from which the soils were formed and also the free drainage conditions. Base saturation of the profile soils varied from 72.15 to 99.02 per cent and mean value was 89.68 per cent. Highest base saturation was observed in HBL series and lowest in YSJ series. This mainly depends on CEC and total exchangeable bases. So, didn't exhibit definite trend in their distribution to profile depth and observed moderate to high base saturation in the study area. The higher base saturation in soil series was due to the prevailing semi-arid climate facilitating less leaching and more accumulation of bases. Thangasamy et al., (2005) also observed direct relation between base saturation and accumulation of bases due to less leaching.

\section{Vertical distribution of forms of carbon Organic carbon}

The organic carbon varied from 1,800 (SGT series) to 6,800 (MTL series) in $\mathrm{mg} \mathrm{kg}^{-1}$ and its declined with depth in all the soil series. Among Ap horizon the highest organic carbon content was recorded in MTL $(6,800$ $\left.\mathrm{mg} \mathrm{kg}^{-1}\right)$ series and lowest in SGT $(2,800 \mathrm{mg}$ $\mathrm{kg}^{-1}$ ) series. The mean value of organic carbon of all the profile was $4,162 \mathrm{mg} \mathrm{kg}^{-1}$ It might be due to accumulation of organic materials in the surface horizons through crop residue, external applications, etc. which generally occurs at the surface. This fractions includes both water soluble and active carbon, hence contributions towards total pool was comparatively more i.e. 20.22 per cent. Similar outcomes were also observed by Sharma et al., (2014) and Jogan et al., (2017).

\section{Water soluble carbon}

The water soluble carbon is easily degraded by microorganisms and plays key role in soil formation. The water soluble carbon distribution is similar to the soil organic carbon in all the soil series of study area, and decreased with depth and this varied from 7.4 to $37.5 \mathrm{mg} \mathrm{kg}^{-1}$. The maximum value was found in MTL series and minimum in NGT series, average value of water soluble carbon content was $19.4 \mathrm{mg} \mathrm{kg}^{-1}$. Among Ap horizon the highest water soluble carbon content was recorded in MTL series (37.5 $\mathrm{mg} \mathrm{kg}^{-1}$ ) and lowest in of SGT series (13.6 mg kg-1). Contribution towards total content was very minute i.e. 0.09 percent.

This might be due to decrease in organic carbon content down the depth and this form of carbon mainly depends up on soil organic matter, which influenced the distribution in soil profiles. Similar observations were also mentioned by Majumdar (2014) and Patil and Patil (2018).

\section{Active carbon}

The active carbon also called as $\mathrm{KMnO}_{4}$ oxidizable carbon or reactive carbon is readily degradable by microorganisms and used as an indicator of change produced by cropping and soil management practices that manipulates SOM content. The active carbon content was ranged from 174.31 to $1335.95 \mathrm{mg} \mathrm{kg}^{-1}$. The mean value of active carbon was $599.26 \mathrm{mg}$ 
$\mathrm{kg}^{-1}$ and highest content was observed in HGK series, while lowest in NPT series. Among Ap horizon the active carbon content was highest (1335.95 mg kg-1) in HGK series and lowest (175.36 mg kg-1) in of JLG series. 2.91 per cent of this fraction accounted towards total-C content in study area. Its content decreased with respect to profile depth in all the profiles of different soil series which is in accordance with OC content of the soil. Surface soil had maximum quantity of active carbon then sub-surface soil and its gradually decreased with respect to OC content in soil. The present findings were in line with those of Benbi et al., (2015) and Madhu (2016).

\section{Inorganic carbon}

The inorganic carbon values ranged from 4,344 (SGT series) to 56,700 (VKP series) in $\mathrm{mg} \mathrm{kg}^{-1}$ and mean value was $16,418 \mathrm{mg} \mathrm{kg}^{-1}$. The inorganic carbon content increased with depth in HHG, BLD, MJR, VKP, NPT, AKT, DNI and MVD series, while KPR series was showed decreasing pattern with profile depth and remaining soil series, did not follow definite trend. Among the Ap horizons, it was lowest $\left(4,728 \mathrm{mg} \mathrm{kg}^{-1}\right)$ in SGT series and highest $\left(45,744 \mathrm{mg} \mathrm{kg}^{-1}\right)$ in VKP series. The higher inorganic carbon content highest in sub-surface horizon compare to surface horizon, which indicates that parent material was alkaline in nature. The similar outcomes were also cited by Patil and Patil (2018). This form of carbon includes other than organic carbon forms and shared maximum per cent (79.78) to total content. This fraction contributed the highest per cent among all other fractions.

\section{Total carbon}

The total carbon content ranged from 6,244 to $61,000 \mathrm{mg} \mathrm{kg}^{-1}$. The total carbon content decreased with depth HHG, YSJ, MTL and
KPR series, while BLD, VKP, NPT, AKT, DNI and SGT series were showed inclining trend with depth and remaining soil series did not follow definite trend. This variation was mainly due to contribution of organic and inorganic carbon pool towards total-C. However, inorganic carbon contribution was more than organic carbon. These findings were in agreement with earlier report of Madhu (2016) and Patil and Patil (2018). The highest total carbon content was observed in VKP and lowest in SGT series. The average value was $20,579 \mathrm{mg} \mathrm{kg}^{-1}$ from all the soil series of study area.

The results pertaining to different forms of $\mathrm{C}$ in soils of Dambal sub-watershed is depicted graphically in Fig. 2.

\section{Correlation between forms of carbon with soil properties Dambal sub-watershed}

Water soluble, organic and active carbon recorded negative correlation with free $\mathrm{CaCO}_{3}$ and $\mathrm{pH}$ and positive correlation with clay, $\mathrm{OC}$ and CEC. This clearly indicated that OC content, water soluble and active carbon content were in positive relation. Organic carbon showed significant negative correlation with $\mathrm{pH}(\mathrm{r}=-0.128 * *)$ and free $\mathrm{CaCO}_{3}(\mathrm{r}=-$ $\left.0.290^{* *}\right)$. Water soluble carbon had significant positive correlation with clay and CEC ( $\mathrm{r}=$ $\left.0.156^{*}\right)$ and $\left(\mathrm{r}=0.462^{*}\right)$ respectively, significant negative correlation with free $\mathrm{CaCO}_{3}\left(\mathrm{r}=-0.225^{* *}\right)$. Active carbon shows significantly and negatively correlated with $\mathrm{pH}$ $(\mathrm{r}=-0.398 * *)$ and free $\mathrm{CaCO}_{3}(\mathrm{r}=-0.612 *)$. Inorganic and total carbon has significant positive correlation with free $\mathrm{CaCO}_{3}(\mathrm{r}=$ $1.000^{* *}$ and $\mathrm{r}=0.978^{* *}$, respectively), suggests that inorganic carbon contributed more to the total carbon. While, significant negative correlation with $\mathrm{OC}(\mathrm{r}=-0.387 * *$ and $r=-0.255^{*}$, respectively). Similar results were also described by Sharma et al., (2014) and Madhu (2016). 
Table.1 Physical properties in soils of Dambal sub-watershed of Mundagri taluk of Gadag district

\begin{tabular}{|c|c|c|c|c|c|c|c|c|c|c|}
\hline \multirow{2}{*}{$\begin{array}{l}\text { Sl. } \\
\text { No. }\end{array}$} & \multirow{2}{*}{$\begin{array}{l}\text { Name of the } \\
\text { soil series }\end{array}$} & \multirow[t]{2}{*}{ Horizon } & \multirow{2}{*}{$\begin{array}{l}\text { Depth } \\
\text { (cm) }\end{array}$} & Sand & Silt & Clay & \multirow{2}{*}{$\begin{array}{l}\text { Textural } \\
\text { Class }\end{array}$} & BD & PD & \multirow{2}{*}{$\begin{array}{c}\text { Porosity } \\
(\%)\end{array}$} \\
\hline & & & & \multicolumn{3}{|c|}{$(\%)$} & & \multicolumn{2}{|c|}{$\left(\mathrm{Mg} \mathrm{m}^{-3}\right)$} & \\
\hline 1 & BGT & Ap & $0-21$ & 22 & 16 & 62 & Clay & 1.24 & 2.60 & 52.31 \\
\hline 2 & HGK & Ap & $0-16$ & 18 & 24 & 58 & Clay & 1.23 & 2.60 & 52.69 \\
\hline 3 & KLK & Ap & $0-16$ & 51 & 20 & 29 & Sandy clay loam & 1.43 & 2.63 & 45.63 \\
\hline \multirow[t]{2}{*}{4} & \multirow[t]{2}{*}{$\mathrm{AKT}$} & Ap & $0-14$ & 38 & 20 & 42 & Clay & 1.33 & 2.62 & 49.24 \\
\hline & & $\mathrm{Bw}$ & $14-36$ & 32 & 16 & 52 & Clay & 1.40 & 2.63 & 46.77 \\
\hline \multirow[t]{2}{*}{5} & \multirow[t]{2}{*}{ BLD } & Ap & $0-9$ & 21 & 18 & 61 & Clay & 1.28 & 2.60 & 50.77 \\
\hline & & $\mathrm{Bw}$ & $9-33$ & 15 & 12 & 73 & Clay & 1.34 & 2.61 & 48.66 \\
\hline 6 & JLG & Ap & $0-28$ & 62 & 14 & 24 & Sandy clay loam & 1.33 & 2.64 & 49.62 \\
\hline \multirow[t]{2}{*}{7} & \multirow[b]{2}{*}{ MTL } & Ap & $0-16$ & 33 & 28 & 39 & Clay loamy & 1.19 & 2.62 & 54.58 \\
\hline & & $\mathrm{Bw}$ & $16-34$ & 34 & 20 & 46 & Clay & 1.22 & 2.63 & 53.61 \\
\hline \multirow[t]{2}{*}{8} & \multirow[t]{2}{*}{ NPT } & Ap & $0-12$ & 30 & 24 & 46 & Clay & 1.29 & 2.61 & 50.57 \\
\hline & & Bwk & $12-29$ & 26 & 16 & 58 & Clay & 1.42 & 2.62 & 45.80 \\
\hline \multirow[t]{3}{*}{9} & \multirow[t]{3}{*}{ YSJ } & Ap & $0-12$ & 23 & 28 & 49 & Clay & 1.23 & 2.60 & 52.69 \\
\hline & & $\mathrm{Bw}_{1}$ & $12-30$ & 27 & 28 & 45 & Clay & 1.36 & 2.62 & 48.09 \\
\hline & & $\mathrm{Bw}_{2}$ & $30-45$ & 27 & 20 & 53 & Clay & 1.48 & 2.62 & 43.51 \\
\hline \multirow[t]{3}{*}{10} & \multirow[t]{3}{*}{ BDT } & Ap & $0-16$ & 50 & 13 & 37 & Sandy clay & 1.36 & 2.63 & 48.29 \\
\hline & & $\mathrm{Bw}_{1}$ & $16-38$ & 46 & 15 & 39 & Sandy clay & 1.41 & 2.64 & 46.59 \\
\hline & & $\mathrm{Bw}_{2}$ & $38-60$ & 37 & 23 & 40 & Clay loamy & 1.47 & 2.64 & 44.32 \\
\hline \multirow[t]{3}{*}{11} & \multirow[t]{3}{*}{ MJR } & Ap & $0-14$ & 57 & 10 & 33 & Sandy clay loam & 1.27 & 2.63 & 51.71 \\
\hline & & $\mathrm{Bt}_{1}$ & $14-38$ & 50 & 16 & 34 & Sandy clay loam & 1.31 & 2.64 & 50.38 \\
\hline & & $\mathrm{Bt}_{2}$ & $38-65$ & 47 & 16 & 37 & Sandy clay & 1.38 & 2.64 & 47.73 \\
\hline \multirow[t]{2}{*}{12} & \multirow[t]{2}{*}{ VKP } & Ap & $0-14$ & 17 & 24 & 59 & Clay & 1.42 & 2.61 & 45.59 \\
\hline & & Bwk & $14-59$ & 50 & 16 & 34 & Sandy clay loam & 1.44 & 2.63 & 45.25 \\
\hline \multirow[t]{3}{*}{13} & \multirow[t]{3}{*}{ CKP } & Ap & $0-18$ & 40 & 16 & 44 & Clay & 1.21 & 2.61 & 53.64 \\
\hline & & $\mathrm{Bwk}_{1}$ & $18-58$ & 25 & 24 & 51 & Clay & 1.39 & 2.62 & 46.95 \\
\hline & & $\mathrm{Bwk}_{2}$ & $58-96$ & 24 & 16 & 60 & Clay & 1.51 & 2.62 & 42.37 \\
\hline 14 & KPR & Ap & $0-25$ & 16 & 28 & 56 & Clay & 1.34 & 2.60 & 48.46 \\
\hline & & $\mathrm{Bw}_{1}$ & $25-58$ & 12 & 30 & 58 & Clay & 1.37 & 2.62 & 47.71 \\
\hline & & $\mathrm{Bw}_{2}$ & $58-99$ & 20 & 21 & 59 & Clay & 1.41 & 2.63 & 46.39 \\
\hline 15 & HBL & Ap & $0-19$ & 25 & 24 & 51 & Clay & 1.30 & 2.61 & 50.19 \\
\hline & & $\mathrm{Bw}$ & $19-53$ & 24 & 26 & 50 & Clay & 1.36 & 2.61 & 47.89 \\
\hline & & Bss & $53-87$ & 22 & 27 & 51 & Clay & 1.43 & 2.62 & 45.42 \\
\hline & & Bssk & $87-124$ & 21 & 23 & 56 & Clay & 1.47 & 2.63 & 44.11 \\
\hline
\end{tabular}


Table.1 Contd.....

\begin{tabular}{|c|c|c|c|c|c|c|c|c|c|c|}
\hline \multirow{2}{*}{$\begin{array}{l}\text { Sl. } \\
\text { No. }\end{array}$} & \multirow{2}{*}{$\begin{array}{l}\text { Name of the } \\
\text { soil series }\end{array}$} & \multirow[t]{2}{*}{ Horizon } & \multirow{2}{*}{$\begin{array}{l}\text { Depth } \\
\text { (cm) }\end{array}$} & Sand & Silt & Clay & \multirow{2}{*}{$\begin{array}{c}\text { Textural } \\
\text { Class }\end{array}$} & BD & PD & \multirow{2}{*}{$\begin{array}{c}\text { Porosity } \\
(\%)\end{array}$} \\
\hline & & & & \multicolumn{3}{|c|}{$(\%)$} & & \multicolumn{2}{|c|}{$\left(\mathrm{Mg} \mathrm{m}^{-3}\right)$} & \\
\hline \multirow[t]{4}{*}{16} & \multirow{4}{*}{ HHG } & Ap & $0-17$ & 57 & 15 & 28 & Sandy clay loam & 1.28 & 2.62 & 51.15 \\
\hline & & $\mathrm{Bw}_{1}$ & $17-48$ & 55 & 16 & 29 & Sandy clay loam & 1.32 & 2.62 & 49.62 \\
\hline & & $\mathrm{Bw}_{2}$ & $48-90$ & 51 & 17 & 32 & Sandy clay loam & 1.40 & 2.64 & 46.97 \\
\hline & & $\mathrm{Bw}_{3}$ & $90-128$ & 48 & 18 & 34 & Sandy clay loam & 1.43 & 2.65 & 46.04 \\
\hline \multirow[t]{3}{*}{17} & \multirow[t]{3}{*}{ MPT } & Ap & $0-29$ & 20 & 24 & 56 & Clay & 1.33 & 2.61 & 49.04 \\
\hline & & $\mathrm{Bt}_{1}$ & $29-77$ & 26 & 16 & 58 & Clay & 1.36 & 2.62 & 48.09 \\
\hline & & $\mathrm{Bt}_{2}$ & $77-130$ & 21 & 17 & 62 & Clay & 1.41 & 2.62 & 46.18 \\
\hline \multirow[t]{4}{*}{18} & \multirow[t]{4}{*}{ MVD } & Ap & $0-21$ & 28 & 19 & 53 & Clay & 1.32 & 2.60 & 49.23 \\
\hline & & $\mathrm{Bt}_{1}$ & $21-49$ & 22 & 21 & 57 & Clay & 1.36 & 2.61 & 47.89 \\
\hline & & $\mathrm{Bt}_{2}$ & $49-81$ & 18 & 20 & 62 & Clay & 1.39 & 2.61 & 46.74 \\
\hline & & $\mathrm{Bc}$ & $81-102$ & 24 & 21 & 55 & Clay & 1.44 & 2.63 & 45.25 \\
\hline \multirow[t]{4}{*}{19} & \multirow[t]{4}{*}{ NGT } & Ap & $0-10$ & 28 & 24 & 48 & Clay & 1.29 & 2.60 & 50.38 \\
\hline & & $\mathrm{Bw}$ & $10-40$ & 16 & 28 & 56 & Clay & 1.34 & 2.61 & 48.66 \\
\hline & & Bwss & $40-80$ & 13 & 29 & 58 & Clay & 1.39 & 2.61 & 47.13 \\
\hline & & $\mathrm{Bc}$ & $80-130$ & 24 & 32 & 44 & Clay & 1.42 & 2.62 & 46.95 \\
\hline \multirow[t]{4}{*}{20} & \multirow[t]{4}{*}{ SGT } & Ap & $0-17$ & 57 & 15 & 28 & Scl & 1.28 & 2.62 & 51.15 \\
\hline & & $\mathrm{Bw}_{1}$ & $17-58$ & 48 & 16 & 36 & Sandy clay & 1.34 & 2.62 & 48.85 \\
\hline & & $\mathrm{Bw}_{2}$ & $58-89$ & 46 & 12 & 42 & Sandy clay & 1.39 & 2.63 & 47.15 \\
\hline & & $\mathrm{Bw}_{3}$ & $89-141$ & 45 & 16 & 39 & Sandy clay & 1.45 & 2.64 & 45.08 \\
\hline \multirow[t]{4}{*}{21} & \multirow{4}{*}{ VRV } & Ap & $0-17$ & 30 & 20 & 50 & Clay & 1.31 & 2.60 & 49.62 \\
\hline & & $\mathrm{Bw}$ & $17-48$ & 34 & 21 & 45 & Clay & 1.37 & 2.62 & 47.71 \\
\hline & & $\mathrm{Bc}$ & $48-95$ & 22 & 24 & 54 & Clay & 1.40 & 2.62 & 46.56 \\
\hline & & Bwk & $95-150$ & 23 & 25 & 52 & Clay & 1.45 & 2.63 & 44.87 \\
\hline \multirow[t]{4}{*}{22} & \multirow[t]{4}{*}{ DNI } & Ap & $0-15$ & 55 & 13 & 32 & Sandy clay loam & 1.33 & 2.63 & 49.43 \\
\hline & & $\mathrm{Bw}$ & $15-35$ & 52 & 18 & 30 & Sandy clay loam & 1.35 & 2.63 & 48.67 \\
\hline & & $\mathrm{Bt}_{1}$ & $35-110$ & 45 & 16 & 39 & Sandy clay & 1.38 & 2.64 & 47.73 \\
\hline & & $\mathrm{Bt}_{2}$ & $110-160$ & 46 & 13 & 41 & Sandy clay & 1.42 & 2.65 & 46.42 \\
\hline \multicolumn{4}{|c|}{ Range } & $12-62$ & $10-32$ & $24-73$ & \multirow[t]{3}{*}{ Sandy clay loam - Clay } & $1.19-1.51$ & $2.60-2.65$ & $42.37-54.58$ \\
\hline \multicolumn{4}{|c|}{ Mean } & 33.27 & 19.97 & 46.77 & & 1.36 & 2.62 & 48.17 \\
\hline \multicolumn{4}{|c|}{ SD } & 13.98 & 5.26 & 11.21 & & 0.07 & 0.01 & 2.63 \\
\hline
\end{tabular}


Table.2 Chemical properties in soils of Dambal sub-watershed of Mundagri taluk of Gadag district

\begin{tabular}{|c|c|c|c|c|c|c|c|c|c|c|c|c|c|c|}
\hline \multirow{3}{*}{$\begin{array}{l}\text { Sl. } \\
\text { No. }\end{array}$} & \multirow{3}{*}{$\begin{array}{l}\text { Name of the } \\
\text { soil series }\end{array}$} & \multirow[t]{3}{*}{ Horizon } & \multirow{3}{*}{$\begin{array}{c}\text { Depth } \\
(\mathrm{cm})\end{array}$} & \multirow{3}{*}{$\underset{(1: 2.5)}{\text { pH }}$} & \multirow{3}{*}{$\begin{array}{c}\mathrm{EC} \\
\left(\mathrm{dS} \mathrm{m}^{-1}\right)\end{array}$} & OC & $\mathrm{CaCO}_{3}$ & \multicolumn{4}{|c|}{ Exchangeable cations } & \multirow[t]{2}{*}{ TEB } & \multirow[t]{2}{*}{ CEC } & \multirow{3}{*}{$\begin{array}{l}\text { BS } \\
(\%)\end{array}$} \\
\hline & & & & & & \multirow{2}{*}{\multicolumn{2}{|c|}{$\left(\mathrm{g} \mathrm{kg}^{-1}\right)$}} & $\mathbf{C a}$ & Mg & $\mathbf{N a}$ & $\mathbf{K}$ & & & \\
\hline & & & & & & & & \multicolumn{6}{|c|}{$\left(\operatorname{cmol}\left(p^{+}\right) \mathrm{kg}^{-1}\right)$} & \\
\hline 1 & BGT & Ap & $0-21$ & 7.29 & 0.16 & 4.7 & 266.2 & 12.7 & 2.9 & 0.17 & 0.34 & 16.11 & 19.28 & 83.56 \\
\hline 3 & KLK & Ap & $0-16$ & 6.78 & 0.14 & 3.6 & 39.7 & 5.6 & 3.5 & 0.12 & 0.18 & 9.37 & 12.29 & 76.23 \\
\hline \multirow[t]{2}{*}{4} & \multirow[t]{2}{*}{ AKT } & Ap & $0-14$ & 7.98 & 0.16 & 4.8 & 151.2 & 11.7 & 2.1 & 0.16 & 0.44 & 14.40 & 16.48 & 87.36 \\
\hline & & $\mathrm{Bw}$ & $14-36$ & 8.09 & 0.21 & 3.7 & 337.5 & 15.8 & 1.6 & 0.21 & 0.19 & 17.80 & 19.94 & 89.27 \\
\hline \multirow[t]{2}{*}{5} & \multirow[t]{2}{*}{ BLD } & Ap & $0-9$ & 6.72 & 0.24 & 3.8 & 41.2 & 16.1 & 4.2 & 0.30 & 0.24 & 20.64 & 25.62 & 80.56 \\
\hline & & $\mathrm{Bw}$ & $9-33$ & 7.28 & 0.20 & 3.2 & 47.7 & 20.8 & 4.5 & 0.21 & 0.19 & 25.50 & 32.59 & 78.25 \\
\hline 6 & JLG & Ap & $0-28$ & 8.10 & 0.12 & 4.2 & 45.3 & 12.7 & 3.4 & 0.43 & 0.31 & 16.84 & 19.31 & 87.21 \\
\hline \multirow[t]{2}{*}{7} & \multirow[t]{2}{*}{ MTL } & Ap & $0-16$ & 8.16 & 0.56 & 6.8 & 141.1 & 25.6 & 6.2 & 0.93 & 0.55 & 33.28 & 35.09 & 94.85 \\
\hline & & $\mathrm{Bw}$ & $16-34$ & 8.57 & 0.45 & 4.7 & 118.7 & 26.3 & 6.8 & 0.86 & 0.35 & 34.31 & 36.03 & 95.23 \\
\hline \multirow[t]{2}{*}{8} & \multirow[t]{2}{*}{ NPT } & Ap & $0-12$ & 8.15 & 0.19 & 4.0 & 41.5 & 26.2 & 6.3 & 1.01 & 0.42 & 33.93 & 38.08 & 89.11 \\
\hline & & Bwk & $12-29$ & 8.11 & 0.21 & 3.6 & 52.5 & 28.5 & 4.8 & 0.61 & 0.59 & 34.50 & 36.64 & 94.15 \\
\hline \multirow[t]{2}{*}{9} & \multirow[t]{2}{*}{ YSJ } & Ap & $0-12$ & 7.54 & 0.22 & 4.6 & 49.5 & 20.2 & 4.8 & 0.27 & 0.21 & 25.48 & 33.92 & 75.12 \\
\hline & & $\mathrm{Bw}_{1}$ & $12-30$ & 6.75 & 0.28 & 4.1 & 51.4 & 22.7 & 4.5 & 0.22 & 0.20 & 27.59 & 38.24 & 72.15 \\
\hline \multirow[t]{3}{*}{10} & \multirow[t]{3}{*}{ BDT } & Ap & $0-16$ & 8.17 & 0.46 & 4.2 & 90.5 & 19.4 & 3.4 & 0.39 & 0.22 & 23.35 & 25.69 & 90.82 \\
\hline & & $\mathrm{Bw}_{1}$ & $16-38$ & 7.93 & 0.58 & 3.7 & 97.1 & 20.4 & 4.2 & 0.42 & 0.20 & 25.18 & 28.75 & 87.57 \\
\hline & & $\mathrm{Bw}_{2}$ & $38-60$ & 8.05 & 0.53 & 2.8 & 93.8 & 21.8 & 4.7 & 0.37 & 0.21 & 26.98 & 30.24 & 89.18 \\
\hline 11 & MJR & Ap & $0-14$ & 6.98 & 0.12 & 4.4 & 46.1 & 10.2 & 3.6 & 0.27 & 0.22 & 14.17 & 19.44 & 72.89 \\
\hline & & $\mathrm{Bt}_{1}$ & $14-38$ & 7.72 & 0.14 & 4.2 & 48.2 & 12.2 & 4.1 & 0.23 & 0.18 & 16.53 & 20.99 & 78.74 \\
\hline & & $\mathrm{Bt}_{2}$ & $38-65$ & 7.28 & 0.08 & 3.3 & 52.3 & 15.3 & 3.3 & 0.31 & 0.21 & 18.87 & 24.79 & 76.13 \\
\hline 12 & VKP & Ap & $0-14$ & 8.09 & 0.17 & 5.6 & 381.2 & 16.1 & 4.6 & 0.23 & 0.32 & 21.25 & 25.26 & 84.12 \\
\hline & & Bwk & $14-59$ & 8.23 & 0.18 & 4.3 & 472.5 & 12.7 & 2.8 & 0.48 & 0.24 & 16.09 & 18.59 & 86.57 \\
\hline 13 & CKP & Ap & $0-18$ & 8.56 & 1.38 & 5.7 & 367.5 & 10.6 & 4.7 & 1.55 & 0.66 & 17.51 & 19.34 & 90.56 \\
\hline & & $\mathrm{Bwk}_{1}$ & $18-58$ & 8.72 & 0.99 & 4.0 & 445.7 & 13.7 & 3.1 & 1.82 & 0.26 & 18.88 & 20.40 & 92.56 \\
\hline & & $\mathrm{Bwk}_{2}$ & $58-96$ & 8.21 & 1.63 & 3.7 & 441.2 & 11.5 & 5.3 & 1.67 & 0.35 & 18.82 & 20.58 & 91.45 \\
\hline 14 & KPR & Ap & $0-25$ & 8.52 & 0.22 & 5.8 & 101.2 & 20.1 & 11.4 & 1.64 & 0.56 & 33.70 & 34.17 & 98.63 \\
\hline & & $\mathrm{Bw}_{1}$ & $25-58$ & 8.31 & 1.34 & 5.3 & 87.5 & 17.7 & 10.7 & 1.47 & 0.32 & 30.18 & 30.97 & 97.43 \\
\hline & & $\mathrm{Bw}_{2}$ & $58-99$ & 8.36 & 1.22 & 3.3 & 51.5 & 9.6 & 2.8 & 2.07 & 0.22 & 14.69 & 15.42 & 95.29 \\
\hline 15 & HBL & Ap & 0-19 & 8.64 & 0.31 & 6.2 & 131.5 & 27.2 & 7.7 & 1.14 & 0.58 & 36.62 & 37.11 & 98.67 \\
\hline & & $\mathrm{Bw}$ & $19-53$ & 8.82 & 0.54 & 4.9 & 121.8 & 18.5 & 9.9 & 1.31 & 0.31 & 30.02 & 30.67 & 97.89 \\
\hline
\end{tabular}


Table.2 Contd.....

\begin{tabular}{|c|c|c|c|c|c|c|c|c|c|c|c|c|c|c|}
\hline \multirow{3}{*}{$\begin{array}{l}\text { Sl. } \\
\text { No. }\end{array}$} & \multirow{3}{*}{$\begin{array}{c}\text { Name of } \\
\text { the soil } \\
\text { series }\end{array}$} & \multirow[t]{3}{*}{ Horizon } & \multirow{3}{*}{$\begin{array}{c}\text { Depth } \\
\text { (cm) }\end{array}$} & \multirow{3}{*}{$\underset{(1: 2.5)}{\text { pH }}$} & \multirow{3}{*}{ 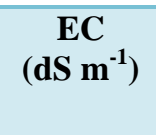 } & OC & $\mathrm{CaCO}_{3}$ & \multicolumn{4}{|c|}{ Exchangeable cations } & \multirow[t]{2}{*}{ TEB } & \multirow[t]{2}{*}{ CEC } & \multirow{3}{*}{$\begin{array}{c}\text { BS } \\
(\%)\end{array}$} \\
\hline & & & & & & \multirow{2}{*}{\multicolumn{2}{|c|}{$\left(\mathrm{g} \mathrm{kg}^{-1}\right)$}} & $\mathbf{C a}$ & Mg & $\mathbf{N a}$ & K & & & \\
\hline & & & & & & & & \multicolumn{6}{|c|}{$\left(\operatorname{cmol}\left(\mathrm{p}^{+}\right) \mathrm{kg}^{-1}\right)$} & \\
\hline \multirow[t]{4}{*}{16} & \multirow[t]{4}{*}{ HHG } & Ap & $0-17$ & 8.04 & 0.23 & 4.1 & 44.7 & 19.1 & 6.7 & 0.80 & 0.32 & 26.92 & 29.40 & 91.57 \\
\hline & & $\mathrm{Bw}_{1}$ & $17-48$ & 8.12 & 0.52 & 3.3 & 45.9 & 12.4 & 6.4 & 0.78 & 0.24 & 19.82 & 21.51 & 92.13 \\
\hline & & $\mathrm{Bw}_{2}$ & $48-90$ & 8.01 & 0.34 & 3.1 & 46.3 & 20.3 & 7.5 & 0.93 & 0.23 & 28.96 & 32.02 & 90.45 \\
\hline & & $\mathrm{Bw}_{3}$ & $90-128$ & 7.82 & 0.86 & 2.5 & 48.6 & 19.0 & 7.8 & 0.82 & 0.27 & 27.89 & 31.26 & 89.23 \\
\hline \multirow[t]{2}{*}{17} & \multirow[t]{2}{*}{ MPT } & Ap & $0-29$ & 8.41 & 0.19 & 6.6 & 88.7 & 12.4 & 6.2 & 1.43 & 0.53 & 20.56 & 21.79 & 94.37 \\
\hline & & $\mathrm{Bt}_{2}$ & $77-130$ & 9.07 & 0.58 & 4.2 & 51.2 & 11.5 & 4.1 & 0.81 & 0.27 & 16.68 & 17.13 & 97.36 \\
\hline \multirow[t]{4}{*}{18} & \multirow[t]{4}{*}{ MVD } & Ap & $0-21$ & 8.29 & 0.37 & 5.3 & 132.9 & 35.3 & 10.5 & 0.43 & 0.21 & 46.44 & 48.87 & 95.02 \\
\hline & & $\mathrm{Bt}_{1}$ & $21-49$ & 8.14 & 0.44 & 4.7 & 138.2 & 37.5 & 8.3 & 0.47 & 0.25 & 46.52 & 49.78 & 93.46 \\
\hline & & $\mathrm{Bt}_{2}$ & $49-81$ & 8.32 & 0.31 & 4.1 & 153.8 & 32.7 & 9.2 & 0.39 & 0.22 & 42.51 & 44.91 & 94.65 \\
\hline & & $\mathrm{Bc}$ & $81-102$ & 8.23 & 0.51 & 3.5 & 165.1 & 29.8 & 7.1 & 0.55 & 0.37 & 37.82 & 40.52 & 93.33 \\
\hline \multirow[t]{3}{*}{19} & \multirow[t]{3}{*}{ NGT } & Ap & 0-10 & 8.74 & 0.24 & 5.8 & 94.5 & 23.9 & 11.3 & 1.54 & 0.61 & 37.35 & 37.91 & 98.52 \\
\hline & & $\mathrm{Bw}$ & $10-40$ & 9.01 & 0.98 & 4.4 & 93.7 & 19.3 & 11.7 & 1.51 & 0.36 & 32.87 & 33.23 & 98.92 \\
\hline & & $\mathrm{Bc}$ & $80-130$ & 8.87 & 1.84 & 2.3 & 96.0 & 16.2 & 8.1 & 1.45 & 0.32 & 26.07 & 26.84 & 97.13 \\
\hline \multirow[t]{4}{*}{20} & \multirow[t]{4}{*}{ SGT } & Ap & 0-17 & 7.36 & 0.09 & 2.8 & 39.4 & 21.6 & 6.2 & 0.67 & 0.29 & 28.76 & 35.52 & 80.97 \\
\hline & & $\mathrm{Bw}_{1}$ & $17-58$ & 7.58 & 0.15 & 2.2 & 43.8 & 24.1 & 6.7 & 0.85 & 0.18 & 31.83 & 38.59 & 82.48 \\
\hline & & $\mathrm{Bw}_{2}$ & $58-89$ & 8.24 & 0.28 & 1.9 & 36.2 & 22.9 & 5.8 & 0.63 & 0.24 & 29.48 & 30.78 & 95.79 \\
\hline & & $\mathrm{Bw}_{3}$ & 89-141 & 7.81 & 0.18 & 1.8 & 39.5 & 22.4 & 7.4 & 0.42 & 0.26 & 30.48 & 34.80 & 87.58 \\
\hline \multirow[t]{4}{*}{21} & \multirow[t]{4}{*}{ VRV } & Ap & 0-17 & 9.18 & 1.07 & 4.8 & 121.2 & 15.2 & 4.8 & 0.83 & 0.59 & 21.42 & 22.90 & 93.52 \\
\hline & & $\mathrm{Bw}$ & $17-48$ & 9.27 & 1.21 & 4.2 & 132.5 & 12.1 & 7.4 & 1.06 & 0.64 & 21.20 & 22.39 & 94.67 \\
\hline & & $\mathrm{Bc}$ & $48-95$ & 8.83 & 1.14 & 3.7 & 433.7 & 16.5 & 6.8 & 1.49 & 0.36 & 25.15 & 28.05 & 89.82 \\
\hline & & Bwk & $95-150$ & 8.04 & 1.02 & 3.1 & 403.4 & 19.1 & 7.3 & 0.94 & 0.90 & 28.24 & 32.62 & 86.57 \\
\hline \multirow[t]{4}{*}{22} & DNI & Ap & 0-15 & 8.29 & 0.16 & 5.7 & 85.2 & 23.9 & 4.1 & 0.49 & 0.30 & 28.79 & 29.92 & 96.23 \\
\hline & & $\mathrm{Bw}$ & $15-35$ & 7.74 & 0.14 & 5.3 & 91.5 & 25.2 & 5.3 & 0.47 & 0.26 & 31.13 & 35.31 & 88.15 \\
\hline & & $\mathrm{Bt}_{1}$ & $35-110$ & 7.18 & 0.17 & 4.8 & 113.4 & 22.4 & 3.6 & 0.53 & 0.20 & 26.73 & 32.10 & 83.27 \\
\hline & & $\mathrm{Bt}_{2}$ & $110-160$ & 7.53 & 0.21 & 3.9 & 128.2 & 20.8 & 4.5 & 0.51 & 0.24 & 26.05 & 30.78 & 84.62 \\
\hline & & nge & & $6.72-9.27$ & $0.08-1.84$ & $\begin{array}{l}1.8- \\
6.8\end{array}$ & $\begin{array}{l}36.2- \\
472.5\end{array}$ & $5.6-37.5$ & $\begin{array}{l}1.6- \\
11.7\end{array}$ & $\begin{array}{l}0.12- \\
2.07\end{array}$ & $\begin{array}{c}0.18- \\
0.90\end{array}$ & $\begin{array}{l}9.37- \\
46.52\end{array}$ & $\begin{array}{c}12.29- \\
49.78\end{array}$ & $\begin{array}{l}72.15- \\
99.02\end{array}$ \\
\hline & & ean & & 8.11 & 0.51 & 4.16 & 136.66 & 19.29 & 5.92 & 0.78 & 0.32 & 26.31 & 29.20 & 89.68 \\
\hline
\end{tabular}


Table.3 Vertical distribution of carbon fractions in soils of Dambal sub-watershed of Mundargi taluk of Gadag district

\begin{tabular}{|c|c|c|c|c|c|c|c|c|}
\hline \multirow[t]{2}{*}{ Sl. No. } & \multirow[t]{2}{*}{ Name of the soil series } & \multirow[t]{2}{*}{ Horizon } & \multirow[t]{2}{*}{$\begin{array}{c}\text { Depth } \\
\text { (cm) }\end{array}$} & Organic-C & $\begin{array}{c}\text { Water } \\
\text { soluble-C }\end{array}$ & Active-C & Inorganic-C & Total-C \\
\hline & & & & \multicolumn{5}{|c|}{$\mathrm{mg} \mathrm{kg}^{-1}$} \\
\hline 1 & BGT & Ap & $0-21$ & 4,700 & 31.2 & 981.56 & 31,944 & 36,644 \\
\hline 2 & HGK & Ap & $0-16$ & 5,300 & 28.7 & $1,335.95$ & 45,636 & 51,044 \\
\hline 3 & KLK & Ap & $0-16$ & 3,600 & 33.6 & 459.47 & 4,764 & 8,364 \\
\hline \multirow[t]{2}{*}{4} & \multirow[t]{2}{*}{$\mathrm{AKT}$} & Ap & $0-14$ & 4,800 & 25.3 & 763.28 & 18,144 & 22,944 \\
\hline & & $\mathrm{Bw}$ & $14-36$ & 3,700 & 17.5 & 697.31 & 40,500 & 44,200 \\
\hline \multirow[t]{2}{*}{5} & \multirow[t]{2}{*}{ BLD } & Ap & $0-9$ & 3,800 & 21.3 & 465.79 & 4,944 & 8,744 \\
\hline & & $\mathrm{Bw}$ & $9-33$ & 3,200 & 16.5 & 415.36 & 5,724 & 8,924 \\
\hline 6 & JLG & Ap & $0-28$ & 4,200 & 13.7 & 175.36 & 5,436 & 9,636 \\
\hline \multirow[t]{2}{*}{7} & \multirow[t]{2}{*}{ MTL } & Ap & $0-16$ & 6,800 & 37.5 & 825.18 & 16,932 & 23,732 \\
\hline & & $\mathrm{Bw}$ & $16-34$ & 4,700 & 32.9 & 781.62 & 14,244 & 18,944 \\
\hline \multirow[t]{2}{*}{8} & \multirow[t]{2}{*}{ NPT } & Ap & $0-12$ & 4,000 & 27.8 & 198.63 & 4,980 & 8,980 \\
\hline & & Bwk & $12-29$ & 3,600 & 21.6 & 174.31 & 6,300 & 9,900 \\
\hline \multirow[t]{3}{*}{9} & \multirow[t]{3}{*}{ YSJ } & Ap & $0-12$ & 4,600 & 14.3 & 526.47 & 5,940 & 10,540 \\
\hline & & $\mathrm{Bw}_{1}$ & $12-30$ & 4,100 & 12.6 & 489.63 & 6,168 & 10,268 \\
\hline & & $\mathrm{Bw}_{2}$ & $30-45$ & 3,400 & 9.4 & 452.17 & 4,824 & 8,224 \\
\hline \multirow[t]{3}{*}{10} & \multirow{3}{*}{ BDT } & Ap & $0-16$ & 4,200 & 17.2 & 564.93 & 11,400 & 15,600 \\
\hline & & $\mathrm{Bw}_{1}$ & $16-38$ & 3,700 & 13.6 & 548.38 & 11,652 & 15,352 \\
\hline & & $\mathrm{Bw}_{2}$ & $38-60$ & 2,800 & 11.3 & 511.42 & 11,256 & 14,056 \\
\hline \multirow[t]{3}{*}{11} & \multirow[t]{3}{*}{ MJR } & Ap & $0-14$ & 4,400 & 22.5 & 211.63 & 5,532 & 9.932 \\
\hline & & $\mathrm{Bt}_{1}$ & $14-38$ & 4,200 & 16.6 & 196.37 & 5,784 & 9,984 \\
\hline & & $\mathrm{Bt}_{2}$ & $38-65$ & 3,300 & 12.2 & 185.26 & 6,276 & 9,576 \\
\hline \multirow[t]{2}{*}{12} & \multirow[t]{2}{*}{ VKP } & Ap & $0-14$ & 5,600 & 25.7 & 726.39 & 45,744 & 51,344 \\
\hline & & Bwk & $14-59$ & 4,300 & 19.2 & 651.23 & 56,700 & 61,000 \\
\hline \multirow[t]{3}{*}{13} & \multirow[t]{3}{*}{ CKP } & Ap & $0-18$ & 5,700 & 29.5 & $1,016.15$ & 44,100 & 49,800 \\
\hline & & Bwk1 & $18-58$ & 4,000 & 24.8 & 984.51 & 53,400 & 57,400 \\
\hline & & Bwk2 & $58-96$ & 3,700 & 19.3 & 812.23 & 52,944 & 56,644 \\
\hline \multirow[t]{3}{*}{14} & \multirow[t]{3}{*}{ KPR } & Ap & $0-25$ & 5,800 & 26.1 & 851.57 & 12,144 & 17,944 \\
\hline & & $\mathrm{Bw}_{1}$ & $25-58$ & 5,300 & 23.8 & 810.83 & 10,500 & 15,800 \\
\hline & & $\mathrm{Bw}_{2}$ & $58-99$ & 3,300 & 14.5 & 767.98 & 6,850 & 10,150 \\
\hline \multirow[t]{4}{*}{15} & \multirow[t]{4}{*}{ HBL } & Ap & 0-19 & 6,200 & 31.4 & 796.32 & 15,780 & 21,980 \\
\hline & & $\mathrm{Bw}$ & $19-53$ & 4,900 & 29.5 & 723.54 & 14,616 & 19,516 \\
\hline & & Bss & $53-87$ & 4,400 & 27.2 & 658.15 & 14,700 & 19,100 \\
\hline & & Bssk & $87-124$ & 2,400 & 23.6 & 605.25 & 16,344 & 18,744 \\
\hline
\end{tabular}


Table.3 Contd.....

\begin{tabular}{|c|c|c|c|c|c|c|c|c|}
\hline \multirow[t]{2}{*}{ Sl. No. } & \multirow[t]{2}{*}{ Name of the soil series } & Horizon & \multirow[t]{2}{*}{$\begin{array}{l}\text { Depth } \\
\text { (cm) }\end{array}$} & Organic-C & $\begin{array}{c}\text { Water } \\
\text { soluble-C }\end{array}$ & Active-C & Inorganic-C & Total-C \\
\hline & & & & \multicolumn{5}{|c|}{$\mathrm{mg} \mathrm{kg}^{-1}$} \\
\hline \multirow[t]{4}{*}{16} & \multirow[t]{4}{*}{ HHG } & $\mathrm{Ap}$ & $0-17$ & 4,100 & 17.2 & 322.56 & 5,364 & 9,464 \\
\hline & & $\mathrm{Bw}_{1}$ & $17-48$ & 3,300 & 15.1 & 302.75 & 5,508 & 8,808 \\
\hline & & $\mathrm{Bw}_{2}$ & $48-90$ & 3,100 & 14.3 & 289.32 & 5,556 & 8,656 \\
\hline & & $\mathrm{Bw}_{3}$ & $90-128$ & 2,500 & 11.7 & 271.85 & 5,832 & 8,332 \\
\hline \multirow[t]{3}{*}{17} & \multirow[t]{3}{*}{ MPT } & $\mathrm{Ap}$ & $0-29$ & 6,600 & 19.2 & 691.38 & 10,644 & 17,244 \\
\hline & & $\mathrm{Bt}_{1}$ & $29-77$ & 5,100 & 15.4 & 623.21 & 16,344 & 21,444 \\
\hline & & $\mathrm{Bt}_{2}$ & $77-130$ & 4,200 & 10.8 & 579.51 & 6,144 & 10,344 \\
\hline \multirow[t]{4}{*}{18} & \multirow[t]{4}{*}{ MVD } & Ap & $0-21$ & 5,300 & 31.5 & 862.04 & 15,948 & 21,248 \\
\hline & & $\mathrm{Bt}_{1}$ & $21-49$ & 4,700 & 27.4 & 841.58 & 16,584 & 21,284 \\
\hline & & $\mathrm{Bt}_{2}$ & $49-81$ & 4,100 & 25.2 & 838.91 & 18,456 & 22,556 \\
\hline & & $\mathrm{Bc}$ & 81-102 & 3,500 & 22.8 & 792.37 & 19,812 & 23,312 \\
\hline \multirow[t]{4}{*}{19} & \multirow[t]{4}{*}{ NGT } & Ap & $0-10$ & 5,800 & 16.7 & 624.25 & 11,340 & 17,140 \\
\hline & & $\mathrm{Bw}$ & $10-40$ & 4,400 & 12.3 & 611.47 & 11,244 & 15,644 \\
\hline & & Bwss & $40-80$ & 3,800 & 9.8 & 591.56 & 12,300 & 16,100 \\
\hline & & $\mathrm{Bc}$ & $80-130$ & 2,300 & 7.4 & 567.11 & 11,520 & 13,820 \\
\hline \multirow[t]{4}{*}{20} & \multirow[t]{4}{*}{ SGT } & Ap & 0-17 & 2,800 & 13.6 & 296.47 & 4,728 & 7,528 \\
\hline & & $\mathrm{Bw}_{1}$ & $17-58$ & 2,200 & 10.3 & 289.13 & 5,256 & 7,456 \\
\hline & & $\mathrm{Bw}_{2}$ & $58-89$ & 1,900 & 8.4 & 264.98 & 4,344 & 6,244 \\
\hline & & $\mathrm{Bw}_{3}$ & 89-141 & 1,800 & 7.9 & 250.36 & 4,740 & 6,540 \\
\hline \multirow[t]{4}{*}{21} & \multirow[t]{4}{*}{ VRV } & Ap & 0-17 & 4,800 & 16.3 & 814.36 & 14,544 & 19,344 \\
\hline & & $\mathrm{Bw}$ & $17-48$ & 4,200 & 13.9 & 747.58 & 15,900 & 20,100 \\
\hline & & $\mathrm{Bc}$ & $48-95$ & 3,700 & 12.6 & 705.96 & 52,044 & 55,744 \\
\hline & & Bwk & $95-150$ & 3,100 & 10.4 & 658.13 & 48,408 & 51,508 \\
\hline \multirow[t]{4}{*}{22} & \multirow[t]{4}{*}{ DNI } & Ap & $0-15$ & 5,700 & 28.5 & 723.68 & 10,224 & 15,924 \\
\hline & & $\mathrm{Bw}$ & $15-35$ & 5,300 & 23.9 & 704.82 & 10,980 & 16,280 \\
\hline & & $\mathrm{Bt}_{1}$ & $35-110$ & 4,800 & 16.2 & 674.85 & 13,608 & 18,408 \\
\hline & & $\mathrm{Bt}_{2}$ & $110-160$ & 3,900 & 14.1 & 651.20 & 15,384 & 19,284 \\
\hline \multicolumn{4}{|c|}{ Range } & $1,800-6,800$ & $7.4-37.5$ & 174.31-1335.95 & $4,344-56,700$ & $6,244-61,000$ \\
\hline \multicolumn{4}{|c|}{ Mean } & $\begin{array}{c}4,162 \\
(20.22)\end{array}$ & $\begin{array}{c}19.4 \\
(0.09)\end{array}$ & $\begin{array}{c}599.26 \\
(2.91)\end{array}$ & $\begin{array}{l}16,418 \\
(79.78)\end{array}$ & $\begin{array}{c}20,579 \\
(100.00)\end{array}$ \\
\hline \multicolumn{4}{|c|}{ SD } & $1,121.45$ & 7.65 & 249.00 & 14,799 & 15,052 \\
\hline
\end{tabular}

Note: Figures in the parentheses indicate per cent contribution towards total. 
Table.4 Correlation between the forms of carbon and soil properties in different soil series of Dambal sub watershed

\begin{tabular}{|l|c|c|c|c|c|}
\hline & Clay & pH & OC & Free CaCO3 & CEC \\
\hline Organic-C & $0.163^{*}$ & $-0.218^{* *}$ & $1.000^{* *}$ & $-0.290^{* *}$ & $0.538^{*}$ \\
\hline Water soluble-C & $0.156^{*}$ & -0.041 & $0.840^{* *}$ & $-0.225^{*}$ & $0.462^{*}$ \\
\hline Active-C & $0.487^{*} *$ & $-0.398^{*} *$ & $0.893^{* *}$ & $-0.612^{*}$ & $0.343^{*}$ \\
\hline Inorganic-C & 0.288 & $0.271^{*}$ & $-0.387 * *$ & $1.000^{* *}$ & 0.156 \\
\hline Total-C & $0.305^{*}$ & 0.290 & $-0.255^{*}$ & $0.978^{* *}$ & 0.245 \\
\hline
\end{tabular}

** Correlation is significant at the 0.01 level; * Correlation is significant at the 0.05 level.

Table.5 Correlation amongst forms of carbon in different soil series of Dambal sub watershed

\begin{tabular}{|l|c|c|c|c|c|}
\hline & Organic-C & Water soluble-C & Active-C & Inorganic-C & Total-C \\
\hline Organic-C & 1 & $0.842^{* *}$ & $0.638^{* *}$ & $-0.387^{* *}$ & $-0.145^{*}$ \\
\hline Water soluble-C & & 1 & $0.753^{* *}$ & $-0.320^{*}$ & $-0.260^{*}$ \\
\hline Active-C & & & 1 & $-0.119^{*}$ & -0.095 \\
\hline Inorganic-C & & & & 1 & $0.937^{* *}$ \\
\hline Total-C & & & & & 1 \\
\hline
\end{tabular}

** Correlation is significant at the 0.01 level; * Correlation is significant at the 0.05 level.

Fig.1 Location map of Dambal sub-watershed

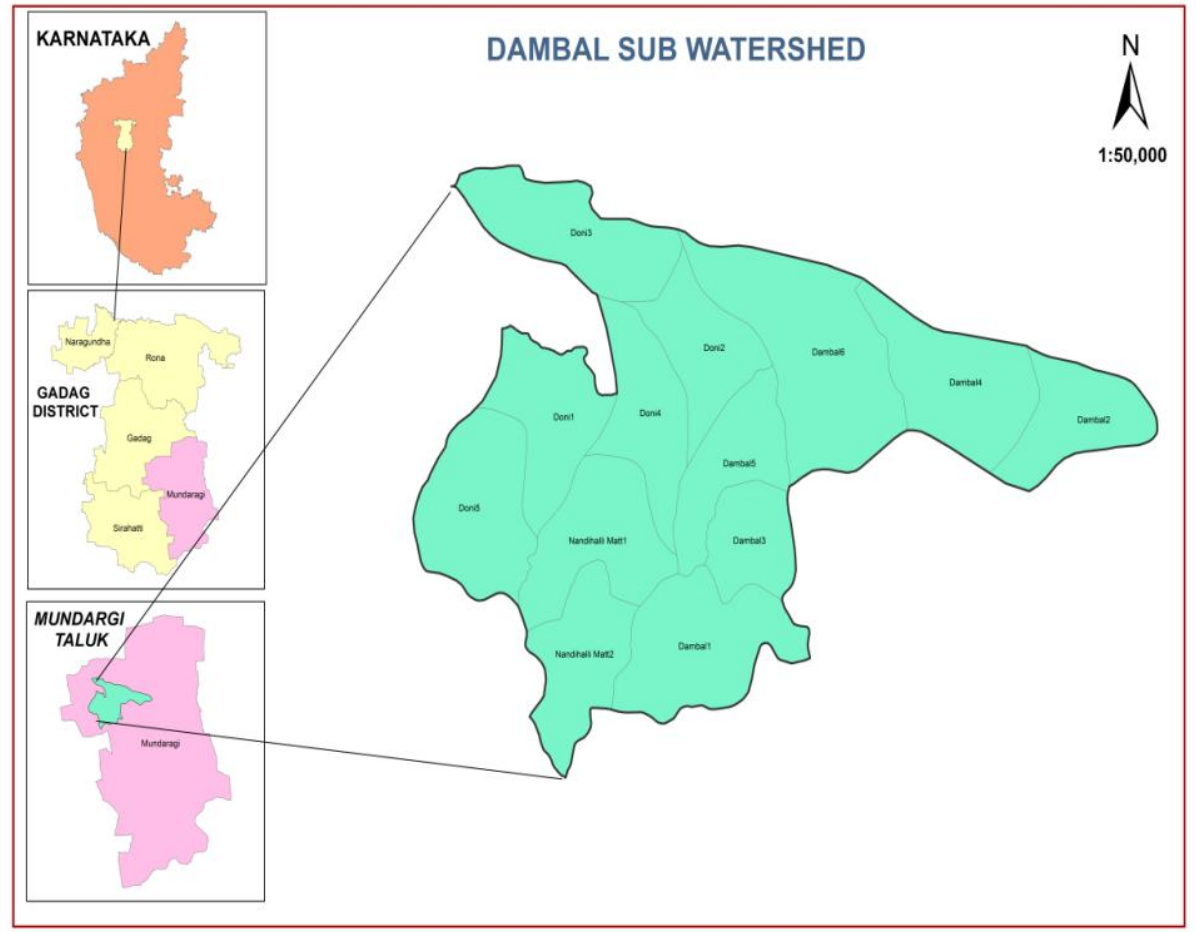


Fig.2

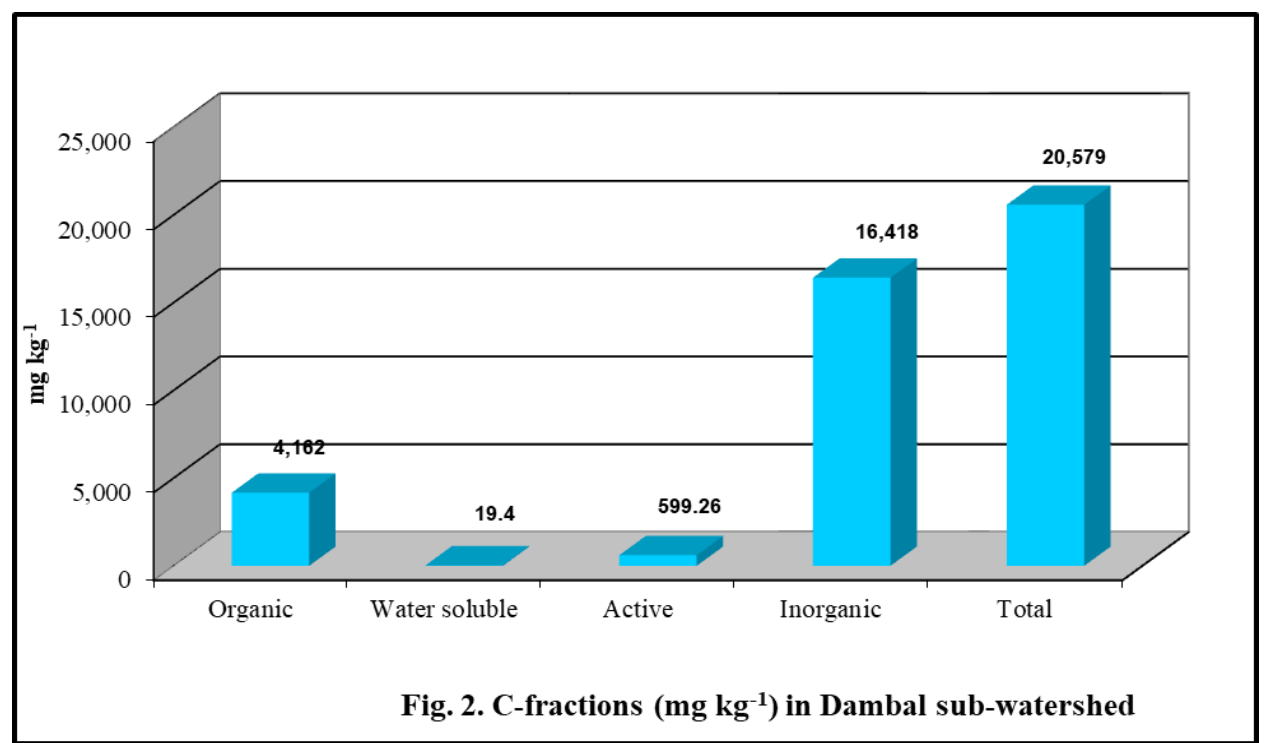

Correlation amongst forms of carbon in different soil series of Dambal subwatershed

Organic carbon showed a significant and positive correlation with water carbon $(\mathrm{r}=$ $\left.0.842^{* *}\right)$ and active carbon $\left(\mathrm{r}=0.638^{* *}\right)$. Water soluble carbon was significantly and positively correlated with active carbon $(\mathrm{r}=$ $\left.0.753^{* *}\right)$. It clearly indicates that increase in organic carbon content leads to the increase in water soluble carbon and active carbon content. Inorganic carbon and total carbon showed negative correlation with water soluble, organic and active carbon, while inorganic carbon significantly and positively correlated with total carbon $(\mathrm{r}=0.937 * *)$, indicates that inorganic carbon contributed more to the total carbon. These results were also similar to the findings of Patil and Patil (2018) in Kanginahal sub-watershed of Northern dry zone of Karnataka and Majumdar and Patil (2017).

In conclusion the results of the present study on forms and distribution of carbon in the soils of Dambal sub-watershed of Mundargi taluk of Gadag district (Karnataka) concluded that, soils were generally sandy clay loam to clay in texture, bulk density and particle density increased with depth and on contrary porosity was decreased with depth. The $\mathrm{pH}$ and EC values ranged from neutral to strongly alkaline and normal to strongly saline respectively. Organic carbon content followed decreasing trend with depth and irregular distribution was observed in free $\mathrm{CaCO}_{3}$. CEC of soil series was average with $\mathrm{Ca}^{2+}$ found as dominant exchangeable cation followed by $\mathrm{Mg}^{2+}, \mathrm{Na}^{+}$and $\mathrm{K}^{+}$. Majority of soils possessed medium to high per cent base saturation. Organic, water soluble and active carbon forms were decreased with depth in all the soil series, whereas inorganic and total carbon did not follow a particular trend. The distribution of carbon fractions in soils is mainly controlled by organic matter, which is the best indicator for assessing the carbon status of the soils. Knowledge about the vertical distribution of forms of carbon in soils was helpful in assessing the long-term carbon supplying capacity of soils. Water soluble and active carbon showed significant positive correlation with organic carbon, whereas inorganic and total carbon showed significant and positive correlation with 
$\mathrm{CaCO}_{3}$. Organic, water soluble and active carbon were significantly and positively correlated with each other, whereas inorganic and total carbon was significantly and positively correlated with each other.

\section{Acknowledgement}

The study was part of the Sujala-III project funded by World Bank through Government of Karnataka. The authors duly acknowledge the support.

\section{References}

Anjali, M. C. and Hebbara, M., 2017, Physical and chemical characterization of selected soil series of Kavalur-2 microwatershed and their classification. $M$. Sc. (Agri.) Thesis, Univ. Agric. Sci., Dharwad, Karnataka (India).

Anonymous, 2017, Land resource inventory atlas of Dambal sub-watershed, Sujala-3 project, UAS Dharwad. pp. 1-9.

Benbi, D. K., Brar, K., Toor, A. R., and Singh, P., 2015, Total and labile carbon pools of soil organic carbon in cultivated and undisturbed soils in Northern India. Geoderma, 237: 149-158.

Black, C. A., 1965, Methods of soil analysis part-I. Physical and mineralogical properties. Agronomy Monograph No.9. American Soc. Agron., Inc. Madison, Wisconsin, USA, pp. 18-25.

Blair, G. J., Lofroy, R. D. B. and Lisle, L., 1995, Soil carbon fractions based on their degree of oxidation and the development of a carbon management index for agricultural systems. Australian J. Agric. Res., 46: 14591466.

Chari, K. M., 2015, Soil resources inventory in Chikmegeri-3 micro-watershed in Koppal district using remote sensing and GIS techniques. Ph. D. Thesis, Univ. Agric. Sci., Dharwad, Karnataka (India).

Dhaliwal, G. S., Gupta, N., Kukal, S. S. and
Kaur, M., 2011, Standardization of automated Vario EL III CHNS analyzer for total carbon and nitrogen determination in soils. Commun. soil Sci. Plant Anal., 42: 971-979.

Eswaran, H. and van den Berge, E., 1992, Impact of building of atmospheric $\mathrm{CO}_{2}$ on length of growing season in the Indian subcontinent. Pedologie, 42: 289296.

Gomez, K. A. and Gomez, A. A., 1984, Statistical Procedures for Agricultural Research, $2^{\text {nd }}$ Ed., John Wiley and Sons., New York. pp. 639.

Jackson, M. L., 1973, Soil Chemical Analysis, Prentice Hall of India Private Limited, New Delhi. pp. 132-148.

Jogan, H., Dasog, G. S., Satyareddi, S. A., Hebbara, M. and Patil, C. R., 2017, Effect of different wastewaters on carbon and nitrogen dynamics in soils of North Karnataka, India. Agric. Res., 6(3): 273-280.

Kirby, M. J., 1985, A basis for soil profile modelling in a geomorphic context. $J$. Soil Sci., 36: 97-121.

Madhu, L., 2016, Assessment of soil carbon stocks in different land use systems in Lakkampura mini-watershed of Jagalur taluk Davanagere district. M. Sc. (Agri.) Thesis, Univ. Agril. Sci., Bangalore, Karnataka (India).

Majumdar, S. and Patil, P. L., 2017, Carbon dynamics under different land use systems of a micro-watershed in Northern transition zone of Karnataka. Oryza, 54(4): 414-419.

Majumdar, S., 2014, Studies on C, N, P and S dynamics under different land use systems of a micro-watershed in Northern transition zone of Karnataka. M. Sc. (Agri.) Thesis, Univ. Agric. Sci., Dharwad, Karnataka (India).

Mc Gill, W. B., Cannon, K. R., Robertson, J. A. and Cook, F. D., 1986, Dynamics of soil microbial biomass and water soluble organic C in Breton L. after 50 years of cropping to two rotations. Canadian J. Soil Sci., 66: 1-19. 
Meenkshi Bai, R., Vidyavathi, G. Y., Yadahalli, G. S., Rudramurthy, H. V. and Rajesh, N. L., 2018, Land resource characterization and soil classification of Pannur North-3 micro-watershed using RS and GIS in Manvi taluk, Raichur district. J. Pharmacogn. Phytochem., 7(1): 671-678.

Nagendra, B. R. and Patil, P. L., 2015, Characterization and classification of soil resources of Shirol West-1 microwatershed. Karnataka J. Agric. Sci., 28(4): 504-509.

Patil, R. S. and Patil, P. L., 2018, Distribution of forms of carbon and carbon stock in different land management units of Kanginhal sub-watershed in Northern dry zone of Karnataka, India. Int. J. Curr. Microbiol. App. Sci., 7(12): 75-83.

Pinki, S., Chikkaramappa, T., Rajeswari, D. and Navya, N. C., 2017, Characterisation and classification of soil resources of Kumachahalli micro-watershed in Chamarajanagar, Karnataka, India. Int. J. Curr. Microbiol. Appl. Sci., 6(12): 319-329.

Piper, C. S., 2002, Soil and Plant Analysis, Hans Publishers, Bombay, India. pp. 368.

Pramod, T. and Patil, P. L., 2015, Characterization and classification of soil resources of Balapur microwatershed. Karnataka J. Agric. Sci., 28(4): 510-517.

Prathibha, K. S., 2016, Assessment of land resources and soil fertility constraints of Kavalur-1 micro-watershed in Koppal district, Karnataka. M. Sc. (Agri.) Thesis, Univ. Agric. Sci., Dharwad, Karnataka (India).
Sharma, V., Hussain, S., Sharma, K. R. and Arya, V. M., 2014, Labile carbon pools and soil organic carbon stocks in the foothill Himalayas under different land use systems. Geoderma, 232: 81-87.

Sitanggang, M., Rao, Y. S., Ahmed, N. and Mahapatra, S. K., 2006, Characterization and classification of soils in watershed area of Shikohpur, Gurgaon district, Haryana. J. Indian Soc. Soil Sci., 54(1): 106-110.

Smeck, N. E., 1973, Phosphorus: an indicator of pedogenic weathering processes. Soil Sci., 115: 199-206.

Sparks, 1996, Methods of Soil Analysis Part 3: Chemical Methods. Soil Sci. Soc. America, USA. pp. 610-624.

Thangasamy, A., Naidu, M. V. S., Ramavatharam, N. and Raghava Reddy, C., 2005, Characterization, classification and evaluation of soil resources in Sivagiri micro-watershed of Chittoor district in Andhra Pradesh for sustainable land use planning. J. Indian Soc. Soil Sci., 53(1): 11-21.

Vinay, L., 2007, Characterization and classification of soil resource of Bhanapur micro-watershed (Koppal district) for land evaluation. $M . S c$. (Agri.) Thesis, Univ. Agric. Sci., Dharwad, Karnataka (India).

Weil, R. W., Islam, K. R., Stine, M. A., Gruver, J. B., Susan, E. and Liebig, S., 2003, Estimating active carbon for soil quality assessment: A simplified method for laboratory and field use. American $J$. Alter. Agric., 18(1): 3-17.

\section{How to cite this article:}

Harshith Gowda, K. S., B. R. Jagadeesh and Patil, P. L. 2020. Forms and Distribution of Carbon in Soils of Dambal Sub-Watershed of Mundargi Taluk, Gadag District, Karnataka, India. Int.J.Curr.Microbiol.App.Sci. 9(08): 783-798. doi: https://doi.org/10.20546/ijcmas.2020.908.084 